\title{
ZMIANY PARAMETRÓW MORFOMETRYCZNYCH JEZIORA STRZESZYŃSKIEGO
}

\author{
ADAM CHOIŃSKI ${ }^{1}$, AGNIESZKA KAŹMIERSKA $^{2}$ \\ ${ }^{1}$ Uniwersytet im. Adama Mickiewicza w Poznaniu, \\ Wydział Nauk Geograficznych i Geologicznych, Zakład Hydrologii i Gospodarki Wodnej \\ ul. B. Krygowskiego 10, 61-680 Poznań \\ ${ }^{2}$ Zespół Parków Krajobrazowych Województwa Wielkopolskiego, \\ ul. T. Kościuszki 95, 61-716 Poznań
}

\begin{abstract}
The paper analyses the changes in the Strzeszyńskie lake basin, located within the borders of the city of Poznań. The study was based on five topographic maps from the years: Moreover, the morphometric parameters of the basins from 1908, 1992 and 2013 were compared. Although the lake is located only a few kilometers from the center of Poznan, its basin has not changed significantly. Undoubtedly, this is influenced by the development of the lake basin. At present, however, there are symptoms indicating the worsening state of the waters.
\end{abstract}

Keywords: bathymetry, lake evolution, catchment, urban lake

\section{WSTĘP}

Powierzchnia wszystkich jezior w Polsce w XX w. zmniejszyła się o około $10 \%$. Już od XIX w. odnotowuje się szybkie tempo zaniku śródlądowych zbiorników wodnych, a proces ten jest obecnie coraz szybszy. Średnie tempo zmniejszania się ogólnej powierzchni jezior na Pojezierzu Wielkopolskim wynosi $0,15 \%$ w ciągu roku (Miller 2003). W przypadku każdego jeziora tempo tego procesu jest silnie zróżnicowane i zależy od wielu czynników naturalnych, zarówno regionalnych, jak i lokalnych (m.in. morfometrii misy jeziornej, zasilania, wielkości i rodzaju zlewni jeziora), a także od czynników antropogenicznych (Kaniecki 1997). Wielkość sedymentacji materii ma szczególne znaczenie, gdyż prowadzi do zaniku jeziora. Jeziora polodowcowe można zaliczyć do najmniej trwałych elementów środowiska geograficznego. Perspektywistyczny wiek tych jezior, szacowany na podstawie zmian ich powierzchni, dla obszaru Polski wynosi około 2 tys. lat. Biorąc pod uwagę dodatkowo procesy związane z wypłycaniem, ich szacunkowy wiek jest jeszcze krótszy i wynosi od kilkudziesięciu do kilkuset lat (Choiński i in. 2012). 


\section{TEREN BADAŃ}

Jezioro Strzeszyńskie jest zlokalizowane w województwie wielkopolskim, w północno-zachodniej części Poznania $\left(52^{\circ} 27^{\prime} 36^{\prime \prime} \mathrm{N}, 16^{\circ} 49^{\prime} 19^{\prime \prime} \mathrm{E}\right)$, na terenie Pojezierza Poznańskiego (fot. 1). Jezioro jest dimiktycznym, naturalnym zbiornikiem polodowcowym o kształcie nieregularnym, ze średnio urozmaiconą linią brzegową oraz z dwoma głęboczkami: południowy o maksymalnej głębokości 17,8 m oraz północno-wschodni o maksymalnej głębokością 17,4 m. Dno Jeziora Strzeszyńskiego, głównie pokryte osadami organicznymi, ma zróżnicowaną konfigurację z rozległymi partiami wypłyconymi, zwłaszcza przy północnym brzegu (Jańczak i in. 1992).

Brzegi jeziora porastają rozległe szuwary z dominacją trzciny pospolitej (Phragmites australis), pałki szerokolistnej (Typha latifolia) i wąskolistnej (Typha angustifolia). Zwłaszcza przy północno-zachodnim brzegu agregacje tworzy kłoć wiechowata (Cladium mariscus) (jedyne stanowisko w Poznaniu). W płytkiej zatoce północnej zbiorowiska tworzą grzybienie białe (Nymphaea alba). Z rzadziej spotykanych gatunków w wodach jeziora stwierdzono rogatka krótkoszyjkowego (Ceratophyllum submersum) (Zgrabczyńska 2008). W strefach płycizn przez wiele lat notowano dobrze rozwinięte płaty roślinności zanurzonej. W roku 2005 największy udział w fitolitoralu miała tworząca rozległe łąki ramienica omszona (Chara tomentosa L.). W płytszych partiach jeziora

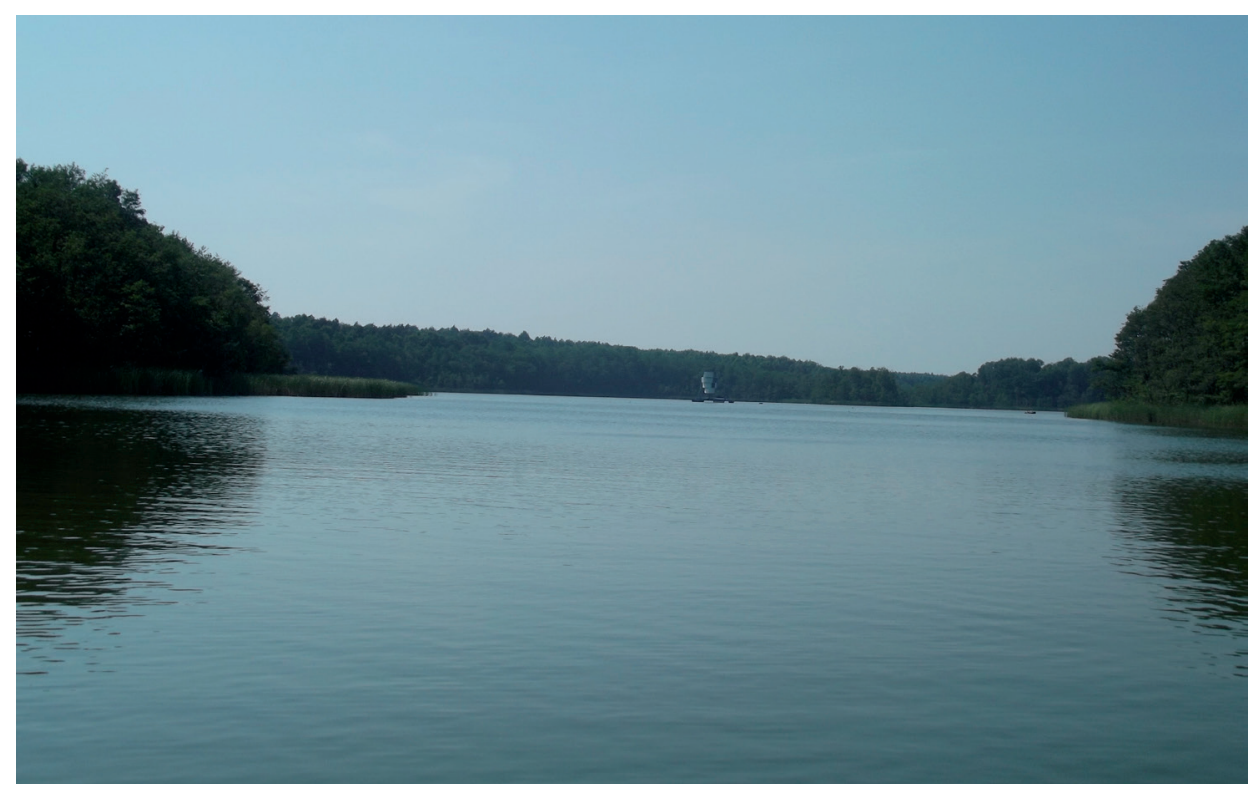

Fot. 1. Jezioro Strzeszyńskie - południowa część zbiornika (fot. A. Kaźmierska)

Phot. 1. Strzeszyńskie lake - southern part of the lake (photo A. Kaźmierska) 
współwystępowała z nią ramienica przeciwstawna (Chara contraria A. Braun ex Kützing), natomiast na większych głębokościach mech zdrojek (Fontinalis antipyretica L.) (Niklaus 2006). W jeziorze notowano również ramienicę kosmatą (Chara hispida L.) i ramienicę delikatną (Chara delicatula C.A. Agardh). Występowały również: rogatek sztywny (Ceratophyllum demersum L.), wywłócznik kłosowy (Myriophyllum spicatum L.), wywłócznik okółkowy (Myriophyllum verticulatum), rdestnica pływająca (Potamogeton Lucent) oraz jezierza morska (Najas marina L.) (Szeląg-Wasielewska 2005; Niklaus 2006; Świerk i Szpakowska 2009).

Zlewnia jeziora, o powierzchni 1116 ha, jest rozbudowana w kierunku północno-wschodnim, skąd doprowadzane są do jeziora wody przez jedyny dopływ powierzchniowy jeziora - Rów Złotnicki. W bezpośrednim otoczeniu jeziora dominują lasy i zadrzewienia, które stanowią ponad $46 \%$ powierzchni zlewni bezpośredniej, a tereny zabudowane stanowią zaledwie $4 \%$. Biorąc pod uwagę całkowitą powierzchnię zlewni, największy udział pokrycia terenu mają grunty orne (33\%) oraz lasy i zadrzewienia (24\%). Tereny zabudowane stanowią około $19 \%$.

Wartościowy obszar pod względem przyrodniczym i dogodna lokalizacja sprawiają, iż Jezioro Strzeszyńskie należy do zbiorników atrakcyjnych dla mieszkańców Poznania i okolic pod względem rekreacyjnym (Świerk i in. 2010) (fot. 2). Jezioro cechuje się wodami eutroficznymi z letnią stratyfikacją

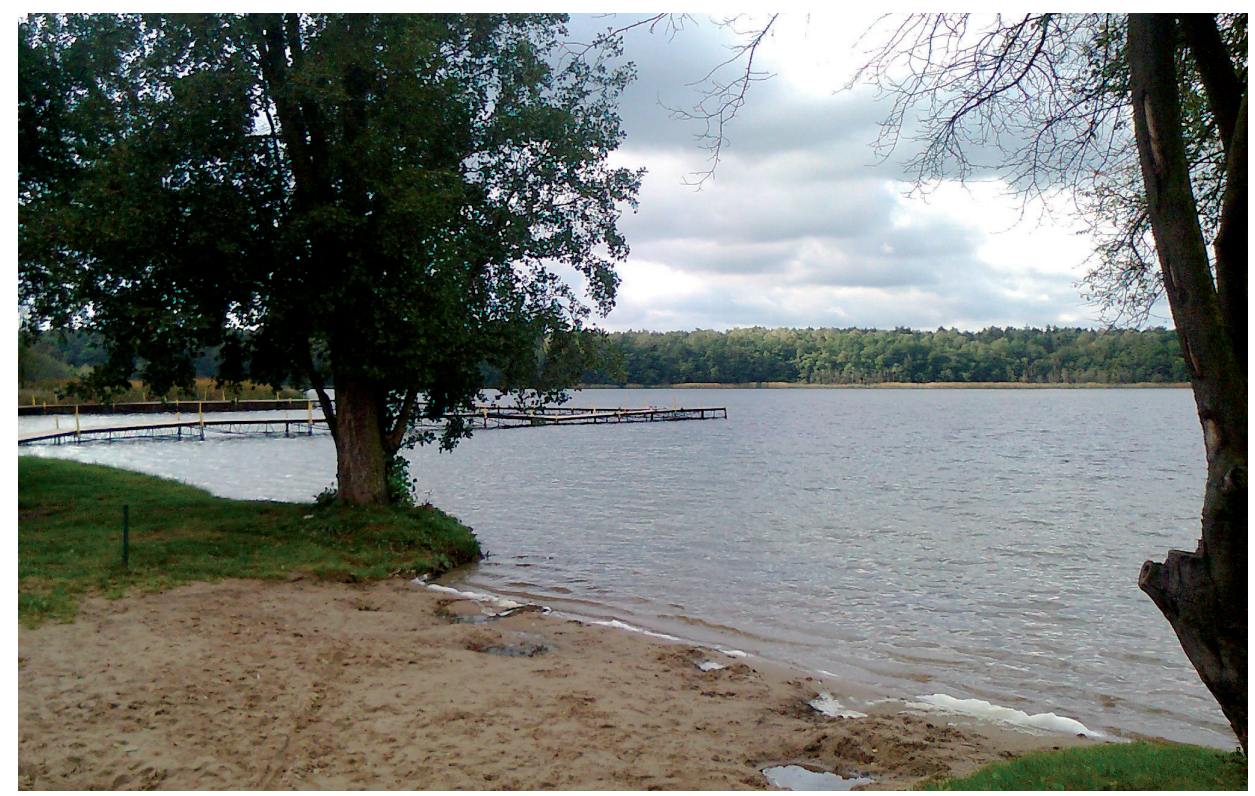

Fot. 2. Przekształcony przez człowieka wschodni brzeg Jeziora Strzeszyńskiego z piaszczysto-trawiastą plażą (fot. A. Kaźmierska)

Phot. 2. The eastern shore of Strzeszyńskie lake altered by man, with a sandy and grassy beach (photo A. Kaźmierska) 
termiczną i deficytami tlenowymi w hypolimnionie (Szeląg-Wasielewska i in. 2015).

\section{METODY BADAŃ}

Dane morfometryczne dla Jeziora Strzeszyńskiego i jego zlewni opracowano na podstawie map topograficznych w skali $1: 25000$ oraz $1: 10000$. Pojemność jeziora obliczono przez zsumowanie splanimetrowanych na planie pól zawartych między izobatami i pomnożenie ich przez średnie głębokości pól. Plan batymetryczny jeziora sporządzono na podstawie badań terenowych przeprowadzonych w czerwcu 2013 r. Pomiar głębokości wykonany był przy użyciu echosondy GARMIN, echosondy ciężarkowej oraz odbiornika GPS GARMIN. Dane uzyskane za pomocą echosondy korygowano pomiarami sondą ciężarkową. W pracy wykorzystano materiały kartograficzne w różnych skalach z XIX, XX i XXI w., pochodzące z zasobu katalogu MAPSTAR. Z uwagi na to, że były one w różnych skalach, sprowadzono je do jednej skali (ryc. 1). Powierzchnię jeziora obliczono, wykonując planimetrowanie na mapie topograficznej.

\section{WYNIKI I DYSKUSJA}

Plan batymetryczny z końca XX w. (Jańczak, Sziwa 1995) - sondowanie wykonano w 1992 r. - oraz z 2013 r. przedstawiono na rycinie 1. Niestety nie ma planu z początku XX w. i istnieją tylko dane liczbowe (Schütze 1920 - sondowanie wykonano w 1908 r.). Zmiany parametrów morfometrycznych na przestrzeni stu lat zestawiono w tabeli 1.

Dzięki dokonaniu aktualizacji planu batymetrycznego oceniono, iż w przeciągu zaledwie 20 lat nastąpiły istotne zmiany zarysu izobat analizowanego zbiornika (tab. 1). Szczególnie widoczne zmiany odnotowano w okolicach głęboczków, zwłaszcza północno-wschodniego. Zanotowano w tym miejscu również większą głębokość maksymalną, która wzrosła o $0,5 \mathrm{~m}$.

$\mathrm{Z}$ przeprowadzonej analizy porównawczej aktualnych pomiarów $\mathrm{z}$ dostępnymi danymi z 1908 r. wynika, że parametry morfometryczne jeziora zmieniły się, lecz niezbyt istotnie. Analizując dane zawarte w tabeli 1, można zauważyć, że powierzchnia jeziora wykazywała tendencję wzrostu od 32 ha (1908) przez 34,9 ha (1992) do 35,4 ha (2013). Wprost proporcjonalny do wzrostu powierzchni był wzrost zasobów wodnych, przy czym w latach 1992 i 2013 były do siebie zbliżone. Głębokość maksymalna w 1908 r. została określona na $16,5 \mathrm{~m}$, a w latach 1992 i 2013 na 17,8 m. W ciągu tak długiego, tj. ponad 100-letniego okresu zazwyczaj głębokość maksymalna maleje. W powyższym przypadku nastąpił jednak wzrost. Wytłumaczyć to można najprawdopodobniej tym, iż pierwsze 


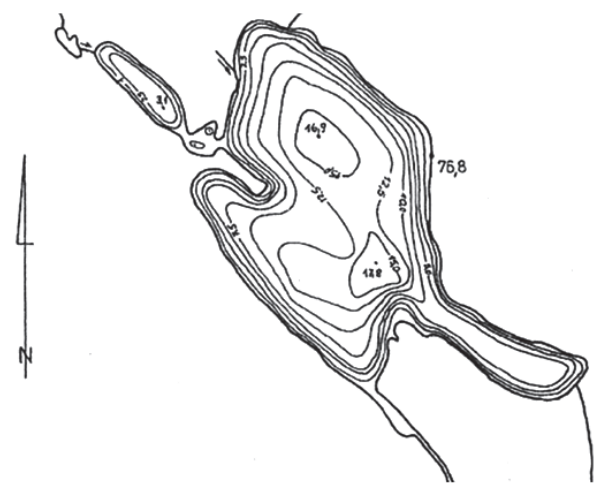

1992

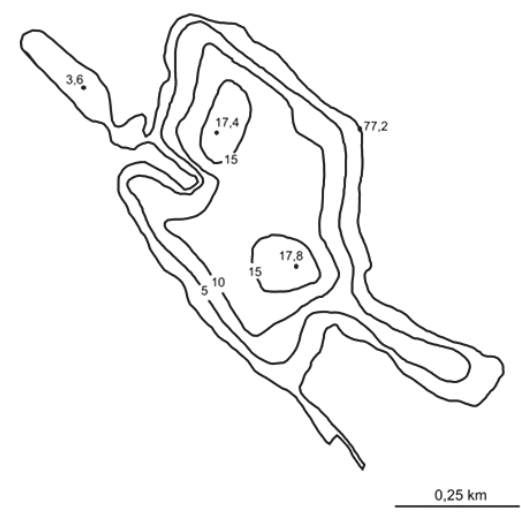

2013

Ryc. 1. Zmiany zarysu izobat jeziora Strzeszyńskiego

Fig. 1. Changes in the outline of the isobath of Strzeszyńskie lake

Tabela 1. Zmiany parametrów morfometrycznych Jeziora Strzeszyńskiego w latach 1908-2013

Table 1. Changes to the morphometric parameters of Strzeszyńskie lake, 1908-2013

\begin{tabular}{lccc}
\hline \multicolumn{1}{c}{ Parametry } & $\begin{array}{c}\text { Schütze } \\
(1908)\end{array}$ & $\begin{array}{c}\text { Jańczak, Sziwa } \\
(1992)\end{array}$ & $\begin{array}{c}\text { Opracowanie } \\
\text { własne (2013) }\end{array}$ \\
\hline Powierzchnia zwierciadła wody [ha] & 32,0 & 34,9 & 35,4 \\
Objętość [tys. m³] & 2700 & 2847,1 & 2834,8 \\
Głębokość maksymalna [m] & 16,5 & 17,8 & 17,8 \\
Głębokość średnia [m] & 8,4 & 8,2 & 8,0 \\
Długość maksymalna [m] & $*$ & 1210 & 1280 \\
Szerokość maksymalna [m] & $*$ & 540 & 550 \\
Długość linii brzegowej [m] & $*$ & 4500 & 4250 \\
Wskaźnik rozwinięcia linii brzegowej & $*$ & 2,17 & 2,02 \\
Rzędna & 76,6 & 76,8 & 77,2 \\
\hline
\end{tabular}

*Brak danych

sondowania nie były zbyt zagęszczone i nie natrafiono na głębokość maksymalną. Głębokość średnia jeziora systematycznie maleje, co świadczy o nieznacznym wypłycaniu się zbiornika.

O ewolucji misy jeziornej decydują nie tylko te procesy, które zachodzą w jej obrębie, ale także te zachodzące w jej zlewni. Kaźmierska (2015) dokonała analizy zmian zagospodarowania zlewni Jeziora Strzeszyńskiego, mając dane dla lat 1977, 1987 i 2012. Mimo że analizowany okres jest względnie krótki - obejmuje jedynie 35 lat - to zaistniałe zmiany są istotne. Przy całkowitej 
powierzchni zlewni jeziora (1116 ha) wzrosły: powierzchnie terenów zabudowanych (od 59 ha do 150 ha), ogródków działkowych (od 0 do 31 ha), roślinności trawiastej (od 139 ha do 201 ha), lasów (od 214 ha do 256 ha), zmalały natomiast powierzchnie gruntów ornych (z 579 ha do 363 ha) oraz sadów (z 48 ha do 11 ha). Jeśli tego typu trendy będą się utrzymywały, może to mieć istotny wpływ na funkcjonowanie zarówno zlewni jeziora, jak i jego misy. Zmieni się bowiem obciążenie biogenami wód i osadów jeziora.

Na rycinie 2 przedstawiono zarysy linii brzegowej Jeziora Strzeszyńskiego sprowadzone do jednej skali. Mapy pochodziły z lat 1830-2014. Mimo upływu blisko dwustu lat linia brzegowa nie uległa istotnym zmianom. Świadczy to o dużej odporności misy jeziornej na jej ewolucję, zarówno w odniesieniu do czynników naturalnych, jak i oddziaływanie człowieka.

Oceniono także odporność jeziora na degradację - II klasa. Oznacza to, że zbiornik ten jest średnio odporny na wpływy zewnętrzne. Nieco inaczej przedstawia się ocena dostawy materii ze zlewni. Pod tym względem jezioro odznacza się podatnością przeciętną, co stanowi o umiarkowanej możliwości dostarczania materii do misy jeziora.

Ponadto obliczono obciążenie biogenami Jeziora Strzeszyńskiego przez: spływ powierzchniowy, źródła punktowe, opad atmosferyczny oraz źródła rozproszone (osoby kąpiące się i ptaki). Przyjmując kryteria Vollenweidera, obliczono
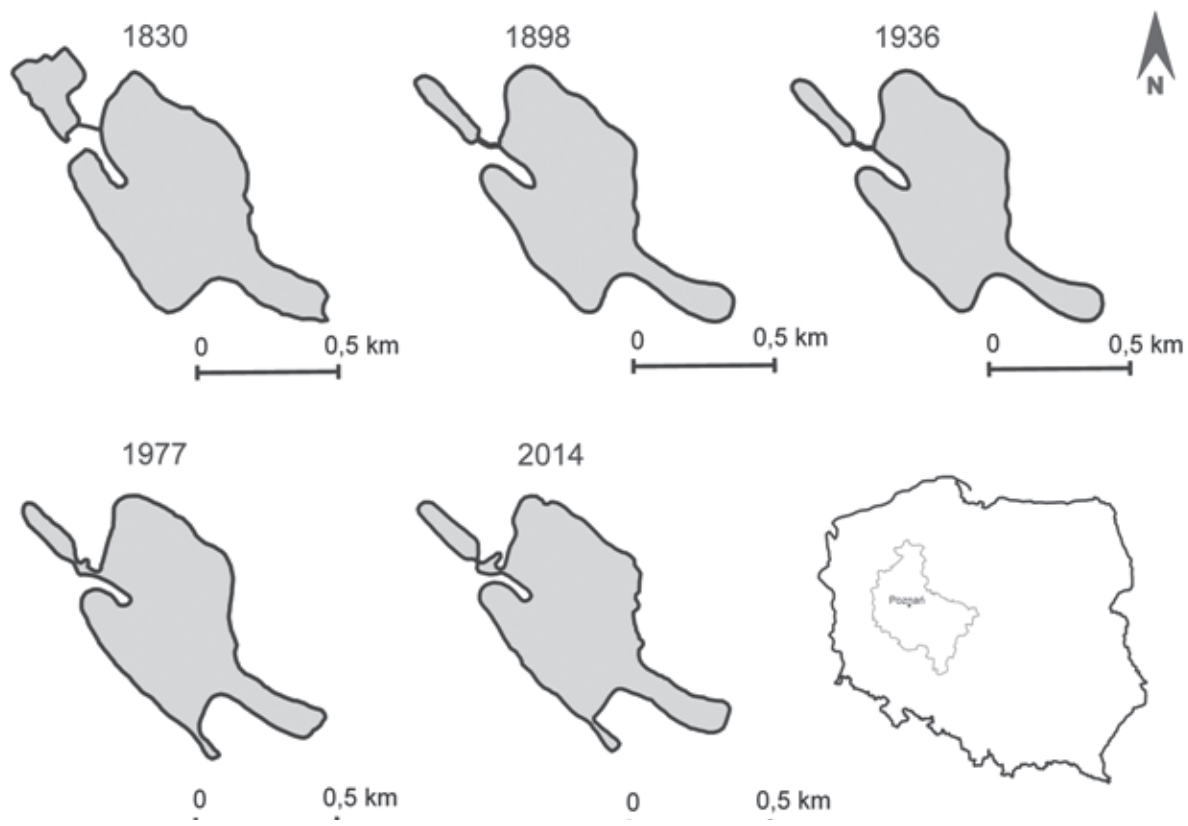

Ryc. 2. Zmiany zarysu linii brzegowej Jeziora Strzeszyńskiego w latach 1830-2014

Fig. 2. Changes in the outline of the shore of Strzeszyńskie lake in the years 1830-2014 
wielkość dopuszczalnego i niebezpiecznego obciążenia fosforem i azotem dla analizowanego jeziora. W przypadku fosforu $\left(416,15 \mathrm{mgP} \cdot \mathrm{m}^{-2} \cdot\right.$ rok $\left.^{-1}\right)$ jest to wielkość prawie pięciokrotnie przekroczona powyżej ładunku dopuszczalnego oraz ponad dwukrotnie powyżej ładunku niebezpiecznego. Dla azotu (11 023,08 $\mathrm{mgN} \cdot \mathrm{m}^{-2} \cdot$ rok $\left.^{-1}\right)$ suma ładunku zewnętrznego została przekroczona ponad ośmiokrotnie powyżej ładunku dopuszczalnego i ponad czterokrotnie powyżej ładunku niebezpiecznego. Na podstawie uzyskanych wyników można zatem przewidywać bardzo niekorzystną dalszą ewolucję jeziora. Symptomem tego może być zmienność występowania ramienic. Otóż są one uważane za czułe bioindykatory trofii jezior z uwagi na preferencje wód od oligotroficznych do słabo eutroficznych. Ich występowanie w jeziorach głębokich świadczy o dobrym stanie ekologicznym ekosystemu (Pełechaty 2006). Sposób użytkowania zlewni, a zwłaszcza zlewni bezpośrednich ma znaczący wpływ na strukturę roślinności jezior. W ostatnich latach zaobserwowano zanikanie łąk ramienicowych w Jeziorze Strzeszyńskim. Proces ten może świadczyć o tym, że jest to wynik postępującej eutrofizacji tego jeziora.

\section{PODSUMOWANIE}

Zmiany parametrów morfometrycznych Jeziora Strzeszyńskiego na przestrzeni niespełna dwustu lat nie są tak bardzo widoczne w porównaniu z innymi jeziorami. Stosunkowo duża głębokość jeziora i duży udział terenów zielonych w bezpośrednim jego otoczeniu przyczyniły się do tego, iż proces wypłycania nie następuje szybko. Jednak symptomem zachodzących niekorzystnych zmian może być na przykład zmniejszenie powierzchni ramienic.

\section{LITERATURA}

Choiński A., Ilyin L., Ptak M., Strzelczak A., 2012: Zmiana batymetrii jeziora Świtaź w latach 1929-2012, Priroda zachidnogo Polissja ta prileglich teritorij. Wolinskij nacionalnij uniwersitet imeni Lesi Ukrajinki. Luck, 55-59.

Jańczak J., Sziwa R., 1995: Charakterystyka morfometryczno-hydrologiczna jezior i zbiorników wodnych Poznania. Wody powierzchniowe Poznania. Problemy wodne obszarów miejskich, UAM, Zakład Hydrologii i Gospodarki Wodnej. Konferencja naukowa, Poznań, 6.11.1995, Wyd. Sorus, Poznań.

Jańczak J., Sziwa R., Kowalik A., Brodzińska B., 1992: Charakterystyka limnologiczna jezior i zbiorników wodnych na terenie miasta Poznania, IMGW, Poznań.

Kaniecki A., 1997: The influence of anthropopressure on water relations in the Wielkopolska Lowland, Geogr. Polon., 68, 65-80.

Kaźmierska A., 2015: Wpływ antropopresji na bakterioplankton i autotroficzny pikoplankton w pelagialu Jeziora Strzeszyńskiego, UAM, Wydział Biologii, Zakład Ochrony Wód Poznań, [maszynopis]. 
Miller P., 2003: Ubywa jezior, Przyr. Pol., 9.

Niklaus B., 2006: Roślinność Jeziora Strzeszyńskiego, UAM, Inst. Biologii Środowiska, Zakł. Ochrony Wód [praca magisterska].

Pełechaty M., 2006: Wykorzystanie ramienic w fitoindykacji, Ekol. i Techn., 3(81), 98-102.

Schütze H., 1920: Die Posener Seen, Stuttgart.

Szeląg-Wasielewska E., 2005: Occurreance of picocyanobacteria during a permanent desmit bloom in a small dystrophic lake, Oceanological and Hydrobiological Stud., 34, 237-246.

Szeląg-Wasielewska E., Jakubowska N., Kaźmierska A., 2015: Changes in phototropic community structure in the vertical profile during summer stratification in eutrophic lake, Fresenius Environmental Bulletin, 24, 355-364.

Świerk D., Szpakowska B., 2009: Ocena wartości wybranych zbiorników miejskich a funkcjonowanie strefy litoralnej. Nauk. Przyr. Technol., 3, 1, 1-11.

Świerk D., Szpakowska B., Dudzińska A., 2010: Wartości rekreacyjne naturalnych i sztucznych zbiorników położonych na terenie Poznania, Probl. Ekol. Krajobrazu, 27, 495-503.

Zgrabczyńska M., 2008: Osobliwości florystyczne użytku ekologicznego „Strzeszyn” w dolinie Bogdanki, Bad. Fizjograf. nad Pol. Zach., 57, 61-67. 